\title{
A Critical Examination of the Question of Personhood in Stem Cell Research
}

\author{
Francis, Diana-Abasi Ibanga \\ Department of Philosophy, University of Calabar Cross River State, Nigeria
}

\begin{abstract}
Stem cell research programme has been celebrated world over as the most promising medical research in the $21^{\text {st }}$ century. However, the method of stem cell research involves the use and unavoidable destruction of human embryo. As a result of this, many theologians, scholars and analysts have condemned the research programme. Their argument is that the embryo use in stem cell research is human person; hence it is immoral. This paper therefore aims at analyzing and examining the issue in order to establish the veracity or otherwise of the moral argument articulated against stem cell research.
\end{abstract}

KEY WORDS:- Stem cell, blastocyst, personhood, hES, Embryo, conception, ensoulment.

\section{INTRODUCTION}

A revolution has been announced: that the genes will become the solution to the health and even life problems of human species" (Iroegbu, 2005). These are the words of excited Pantaleon Iroegbu. Jeremy Rifkin describes it as a great transition from the industrial age to the "biotech century". Indeed, one of the newest scientific revolutions in the world today, at least as at the time of beginning this work, is the stem cell research programme. Yet, at the heart of this overwhelmingly radical medical research project lays a controversy about its moral accountability. Stem cell research is such a significant project that Pantaleon Iroegbu (2005) underscores that it is "the arrival at the roots of research on human cells and thereby at the roots of how to handle our health and life problems". Stem cells are the most elementary aspect of the human being. They are the basic cells of the human person. In other words, stem cells are the mother cells from which all other cells of the body are derived.

Medical researchers all over the world, widely submit that stem cell research has the potential to dramatically alter approaches to understanding and treating diseases, and to alleviate suffering. Medical scientists hope to use, in the future, knowledge acquired through stem cell research to treat a variety of diseases and ailments - from spinal cord injuries and Parkinson's disease to cancer and diabetes, from heart damage and brain damage to deafness and blindness as well as to birth defects and behavioural abnormalities, and even HIV! The anticipatory list of stem cell therapies is long. Already medical scientists have started making gains with their research into stem cells. For example, "in 2003, researchers successfully transplanted retinal stem cells into damage eyes to restore vision. Using embryonic stem cells, scientists were able to grow a thin sheet of totipotent stem cell in the laboratory. When these sheets were transplanted over the damaged retina, the stem cells stimulated renewed repair, eventually restoring vision" (Avasthi et al, 2008). And in June 2005 researchers at the Queen Victoria Hospital of Sussex, England, were able to restore the sight of forty patients using the same technique (Avasthi et al, 2008). Nancy Pelosi, the former Speaker of the United States House of Representatives, re-echoed from fellow congress members, designating it "medical miracle", and described the stem cell as having the biblical power to cure (Iroegbu, 2005).

These imply that a good mastery of stem cells, which can only come through further and persistent research portends novels for the understanding, and consequently for the cure of health problems of human species. In spite of this fact, stem cell research programme had been resisted, in some quarters, with a barricade of moral and religious arguments. Hence, the stem cell research project is under grave threats and could grind to a halt, if the hearts of political leaders are wheeled to the wrong side of the debate. This study, therefore, is undertaken with the intention to critically examine the moral questions raised concerning stem cell research. The debate is raging on, and it has already been caught in the whirl wind of moral controversies that usually prey on scientific revolutions.

Suffice it to say that the entire project of stem cell research does not generate ethical issues - although "it should". For example, research into adult stem cells does not generate the kind of ethical issues instigated by human embryonic stem (hES) cell research. It is important to point out however that ethical issues involving adult stem cell research have been obscured by embryonic stem cell research. Nevertheless, what are ethically at issue in this work are the moral controversies that surround the hES cell research, even though I view the entire stem cell research as an integrated enterprise. 
Meanwhile, the moral questions brought to bear on stem cell research include the questions of right to life, human dignity and personhood as well as allegation of playing God. However, the most fundamental is the question: when does human personhood begin? It is on this question - when does human personhood begin that the entire moral controversies surrounding stem cell research are anchored. Hence, this study focuses on the personhood question.

Philosophical effort to critically examine the moral controversies surrounding stem cell research is very significant to the future of stem cell research project. Karl Popper stated that getting the question right is fundamentally important to research efforts. This work hope to define the most authentic and fundamental moral question that is prevailing against stem cell research, with the hope to show whether or not the moral issues brought to bear on stem cell researches are wrongly routed, hence either dismissible or justifiable. I anticipate that by embarking upon a critical examination of the personhood question in stem cell research, I will be able to illuminate the controversy with philosophical and logical clarification; thereby lay the foundation to dismiss or justify other moral questions.

\section{WHAT IS STEM CELL}

Stem cells are unspecialized cells that are able to divide and produce copies of themselves and having the potential to differentiate, that is, to produce other cell types in the body (Hug, 2006). Stem cells have also been defined as non-specialized cells that have the capacity to divide indefinitely in culture and to differentiate into more mature cells with specialized functions (Iroegbu, 2005). Stem cells can be described as "cells of the stem", that is to say "they are those cells that are to be found at basic being of the human person." They are "the mother cells, from where all other cells are derived." They are the basic cells, the most elementary parts of the body, "the origin of other cells in the body" - the corner stone of the body. Citing United States National Institute of Health, Iroegbu (2005) wrote:Stem cells have the remarkable potential to develop into many different cell types in the body. Stem cells can divide continuously and thereby provide replenishment to the other body parts. As long as the person is alive, stem cells will continue to divide and provide what the weaker parts of the body needs. Stem cells are so to say a repair system.

Moreover, stem cells perform its functions by dividing and multiplying and differentiating into other cell types in the body. However, each new differentiated cell "has the potential to either remain a stem cell or become another type of cell with a more specialized function" (Iroegbu, 2005). So it could be said that stem cell is the cell of cells, the primordial cell, the basic cell, the native cell, the primary cell, the primitive cell, the prima cellus of the body.

\section{CLASSIFICATION OF STEM CELLS}

There are various types of stem cells - which are classified in accordance with its capacity to differentiate into other cell types. In other words, the classification is done in regard to "how many different types of cells they are able to produce, their function or role within the cellular structures the organism" (Iroegbu, 2005). The various types of stem cells we have are; unipotent, totipotent, pluripotent and multipotent, embryonic, and adult stem cells. Iroegbu's classification of stem cells into unipotent, totipotent, etc is according to the behaviour of the stem cells. However, it is my opinion that stem cell should not be classified along behavioural pattern but in accordance with their sources. My position is predicated on the fact that embryonic stem cell (Irogbu's stem cell type) can be cultivated to become totipotent. Of course most embryonic stem cells are totipotent in nature. Hence, the two main classes of stem cells we should have are embryonic and adult stem cells.Embryonic Stem Cell: Embryonic stem cells are stem cells that are harvested from the pre-implantation embryo called blastocyt. In other words, they are primitive cells that are undifferentiated and cultured from the blastocyt. They are known to be the unspecialized precursors of all other cells in an organism. Citing Boomsma, Teo and Calbreath (2006) wrote: "Embryonic stem (ES) cells typically originate from blastocyst stage embryos that are formed approximately six days after fertilization in the human." This means that embryonic stem cells are derived from the inner cell mass of the blastocysts. Iroegbu (2005) noted that embryonic stem cells are not embryos and thereby cannot produce the foetus-forming cell types such as trophectoderen cells; but they nevertheless remain totipotent and basic cells of the human body. In other words, embryonic stem cells have inherent character of pluritotency; yet they can be cultured to become totipotent stem cells. Jill Oliphant (2007) summarized it thus: stem cells obtain from very early embryo are totipotent - they can become any kind of body cell.

Adult Stem Cell: Adult stem cell is the other type of stem cell. They are stem cells that are harvested from the tissue of an adult person. Since they are found in the tissues of an adult person, they are described as "undifferentiated cells found in a differentiated tissue in an adult organism" (Iroegbu, 2005). They have the capacity to become a variety of cells, but not all. In other words, adult stem cells have inherent character of multipotency - that is, they can renew themselves and yield limited range of cell types. However, adult stem cells can be cultured to become pluripotent stem cells. Adult stem cells are not universally productive in the 
same way as the embryonic stem cells. They are derived from a variety of sources including cord blood, autopsy tissue, bone narrow, and tissues of patients themselves (Teo and Calbreath, 2006). Iroegbu (2005) however noted that with certain limitations, adult stem cells have the potency to differentiate to yield all the specialized cell types of the tissue from which it originated. This is a sharp contrast to the embryonic stem cells.

\section{THE QUESTION OF PERSONHOOD OF THE EMBRYO}

The question of personhood of the blastocyst, noted in our introduction, is the fountainhead of all the moral questions generated by embryonic stem cell research. In other words, all the moral questions involved in stem cell research begin and end with the question of personhood of the blastocyst. Hence, it is our belief that if we effectively discuss the question we might as well have answered all other moral questions involved in the research. In order to achieve a comprehensive and effective work we have sub-divided this section into subsections namely: religious, medico-scientific, legal and philosophical perspectives.

At one end of the debate, it is argued that blastocysts are human persons with full moral status - therefore research that involved inevitable destruction of blastocyst should stop immediately. At the other end, it is argued that the blastocyts is not a human person and does not have moral status - hence research that involved inevitable destruction of the blastocyst should continue without restriction. There is also the intermediate position which has suggested that the embryo is not yet a human person until the point of vitality (some point between fertilization and birth) - so, since hES cell research involve use of pre-vitality embryos in the research, it should be allow to continue under certain conditions. A consensus has not been reached amongst the contending parties in the debate. As one looks at this question, it becomes apparent that the answers are not black and white, and that there is much room for disagreement and debate.

Religious Perspective: When we say religious perspective, it sounds as if there is one unified religious system or plurality of religious systems saying the same thing. Unfortunately, religious views on the personhood of the blastocyst are as many as the religions we consider. However, with the exception of Christianity, all other religious systems under our review are precise and distinct in their view about the embryo. This does not mean that there are no groups or sects within each of the major religions that hold contrary views on the morality of stem cell research. Our position is that Christianity, as noted by Boomsma (2004), is severally and deeply divided in its views about the hES cell research. Hence, the bulk of our argument, here, shall engage the Christian spectrum, more than any other, in the debate - due to the fact that much of the religious opposition to stem cell research comes from the Christian religion.

Lori Knowles (2010) observed that "articulated religious opinions about stem cell research primarily deal with the moral acceptability of hES cell research, based on whether the blastocyst are viewed as persons." For most religions, human embryos are persons from the moment of 'ensoulement'. Yet, there is differing opinions on when ensoulment occurs, even within the context of a particular religion. For some religions, ensoulment occurs at the moment of conception, while for others ensoulment takes place some weeks or months after conception. Still for some other religions, such as the Rosicrucian Order, ensoulment does not take effect until birth (Ikube, 2010). These differing opinions signal the diversity and plurality of views held by and within the major world religions.

In Islam, according to Kristina Hug (2006), the majority opinions through the ages "have accepted the morality of abortion either before the fortieth day or the fourth month of pregnancy." Although a minority belief indicates that ensoulment occur forty days after conception, it is generally accepted by majority of Muslim scholars that ensoulment takes place 120 days after conception. Hug argues that the Qua'ran "provides no criteria for when the 'breathing-in' of the soul occurs in the fetus and the thinkers make a distinction between a biological and a moral person, placing the stage of the moral person after the first trimester of pregnancy." Since the blastocyst is not regarded as a moral person, it follow that technically Islam does not oppose hES cell research.

On the other hand, Knowles (2010) argues that "what remains controversial in the Muslim world is creating embryos for the purposes of research." For example, in Egypt, a conservative Islamic country, "the Muslim head of the Egyptian Medical Syndicate stated that embryos are early human life and should never be used in research" (Ibid). However, this opposition is not total. For example, the Chairman of the Islamic Law Council of North America has declared that the blastocyst "have no potential to become human beings," since they lie outside the womb, hence hES cell research is acceptable under Islamic law (Ibid). In addition, the Fatwa Committee, in accordance with Singapore Bioethics Advisory committee, made it clear that the blastocyst is not a human person therefore their involvement in research is permitted under Islamic law (Segura and Delgado, 2010). However, what we have drawn from here is that the blastocyst is not a human person with full moral status; hence its use in hES cell research is never immoral.In Judaism, a religion based on Jewish culture and rabbinical law, the blastocyst is not regarded as human person. Knowles (2010) argues that "there is no consensus on when ensoulment occurs, but generally it is thought to occur sometime after the fortieth day." 
Seguara and Delgado (2010) add that human life, in Judaism, begins after forty days. In spite of that, under Jewish law Halcha the embryo does not become a person nefesh until the head emerges form the womb. That is to say, it is conferred status of human personhood only it emerges form the woman's body." In addition, Daniel Lasker (2005) stated: The Talmud [one of the sources of Jewish Law] compares a fetus to the mother's thigh, namely it is not yet an independent life... indicates that a fetus is not considered a human being who would be protected by the prohibition of murder... Furthermore, the Talmud states that up until forty days of life, the fetus is 'merely water', and even a fetus older than 40 days was never a full human being.Knowles (2010) adds that "gametes and embryos outside a human body do not have any legal status under Jewish law." Once again, we establish that Judaism does not recognize the blastocyst as a human person until birth, therefore its use in hES cell research is not morally objectionable.

In Hinduism and Buddhism, pantheistic religion, Knowles argues that moment of ensoulment differs by and within Hinduism and Buddhism. Conception of personhood is based on a more fundamental concept of reincarnation and Karma while traditional Hindu belief marks conception as the beginning of soul rebirth from a previous life, later Hindu traditions places the beginning of personhood between three and five months of gestation or even seventh month (Ibid). Knowles however argues that most Buddhist have adopted the classical Hindu teaching which places personhood conception. This is therefore an indication that there are no central unified tenets in Hinduism and Buddhism about the beginning of human personhood. Although there is no Buddhist or Hinduist teaching that directly and effectively addresses the moral issues in hES cell research, it has found grounds to oppose it. The opponents of hES cell research within Hinduism and Buddhism argue that the blastocyst is a human person, hence the principle of ahimsa - which prohibits the harming of living creatures should apply. For example, Somparn Promta (2004) argues that:

Abortion is equated to killing a human being, so committing an abortion violates the first clause of the five precepts... [Although] the Buddha never claims that a woman confronting such a dilemma must not commit abortion [suppose she decides to abort the fetus] ... However, Buddhist ethics still continues to claim that abortion is the killing of a human being.In spite of that, Segura and Delgado (2010) note that Hinduism accepts hES cell research despite ascribing personhood to the embryo from conception. Hug (2006) argues that it therefore suggests that Buddhism could accept research on non-sentient embryos ahead of day fourteen of their development. Consequently, it could be argued that it is inconsequential whether or not the blastocyst is a person, but that research involving it should not cause harm to it. The basic thrust of Hinduist and Buddhist views on hES cell research is that the blastocyst is a human person from conception (although, minority opinion suggested three to seven month as beginning of life), yet since the blastocyst has not yet developed sentience, using it in research is not immoral since it cannot be harmed.

Turning now to Christianity, we observe that opinions are evenly divided on the question of personhood of the blastocyst. The official position of Greek Orthodox and Roman Catholic churches had declared that human personhood begins at conception and that the blastocyst has the same moral status as human person (Knowles, 2010) This means that the inevitable destruction of the blastocyst during hES cell research is regarded by those churches as killing of innocent human beings. The Congregation for the Doctrine of Faith, cited by Nicanor Austriaco (2008), put it thus: From the time that the ovum is fertilized, a life is begun which is neither that of the father nor of the mother, it is rather the life of a new human being with his own growth. It would never be made human if it were not human already.Articulating Catholic official position, Austriaco argues that "it is incorrect to say that the human embryo is a potential human being. Rather, it is a human being with great potential...one is either a human being or not one at all” (Ibid).

The Protestant Church is sharply divide on the moral status of the embryo, and seems to have no official position at all on hES cell research. Knowles (2010) quoted Ronald Green, a leading protestant theologian, as testifying before US National Bioethics Advisory committee that "that is not to say that we have no opinion or do not care about their rightful status before God. But officially, we have never declared that we regard embryos as persons." This anarchy within the protestant church manifested itself in the war of words between leading Protestant theologians - Boomsma and Teo \& Calbreath. Robert Boomsma (2004), on the one hand, argued that although conception is a common stage chosen by many evangelical Christians for personhood to begin, it is hard to justify choosing that stage of embryonic development as moment when essential humanness is present. Adrian Teo and Donald Calbreath (2006), on the other hand, argued that "based on the doctrine of predestination... Christians have traditionally embraced the assumption that human life, uniquely created in the image of God for God's own purpose is valuable and is to be protected from undue violence from the point of conception." In a brief, while Boomsma argues that human personhood does not begin at conception but at vitality, Teo and Calbreath argue that personhood necessarily begins at conception.

In addition, Ireogbu noted that there are two broad views, in Christianity, concerning the exact stage human personhood begins. He classified the opinions in Christianity into what he described as "simultaneous animation theory and successive animation theory". While for the simultaneous animation group ensoulment takes place at conception - signifying the beginning of human personhood, the successive animation group believes that the 
embryo does not become a person until ensoulment occurs after the twinning stage - fourteen days from conception (Iroegbu, 2005). He argues further that the bible has no exact word on the precise beginning of human life. However as noted by Green (cited in Knowles, 2010), many Christians would agree that personhood begins at conception but that the blastocyst "have an important but lesser status."

Medico-Scientific Perspective: The question of personhood of the blastocyst in medical science is based almost entirely on empirical investigation of the behaviour of the blastocyst. Pure science is expected to be value-free. Science, in a positive sense, deals with empirical, observable, testable facts. Science and values are said to be "like oil and water" - because values are not considered to be objective whereas science is objective. Values are surrounded by metaphysical precipitations. Delgado and Segura (2010) argue that although the original precept is that science and values are like oil and water, they are inextricably linked. Indeed science would have been less problematic if it had limited its investigation to mere objects, and scientists carrying out research for research sake. But the moment science begun to investigate man it lost its value-free status and had to deal or struggle with metaphysical cobwebs which surrounds the reality of man. This struggle is glaringly evident in medical science where man is the subject of research.

Now, what does medical science have to say on the personhood controversy of the blastocyst. According to Hug (2006), some scientists argue that:

There is no significant dividing line in continuum of physical growth between an embryo and a developed human. Since a developmental point at which personhood is acquired cannot be pointed out, individuals are counted as human beings at their embryonic stage as well as their developed stage... Human embryos differ from other human beings not in what they are, but in their stage of development. A human embryo is a human being in the embryonic stage. Furthermore, Austriaco (2008) argued that:

The recent biological research has demonstrated that the origin of individual human being can be traced back to fertilization... [Hence] the embryo is unique because fertilization brings together a unique combination of chromosomes from both father and mother. A distinctive combination of genes which distinguishes the embryo from any other cell in the body... the forty-six chromosomes is the defining genetic features of human species.

It is also argued that the blastocyst is a human person because its individuality has been defined by the presence of body axes, the coordinate system that tell the body where is up and down, right and left, front and back. John Noonan (1994) argues that for the fact that there is presence of human genetic code in the blastocyst, the blastocyst is human. Besides, the opponents of hES cell research argue that the blastocyst is a human person for the fact of the presence of the genome which distinguishes it from the parent - "genetically-distinct organism, separate but dependent upon the mother, and fully capable of internally-directed growth and active selfintegration" (Teo and Calbreath, 2006).

On the contrary, pro-hES cell research group argues that even if there is no dividing line in human development where personhood occur, the blastocyst does not have the psychological, physiological, emotional or intellectual properties that is often associated with personhood - hence, the blastocyst is not a human person (Hug, 2006). Boomsma (2004) argues that one of "the approaches to determine the status of the embryo is to identify a developmental stage where full human status is present" - for him, this stage is after twinning stage when the nervous system begin to form. Hug (2006) argues that "it may also be that the formation of the nervous system is the landmark for the definition of life, since this is then that the possibility of sensation exists." He argues further that the blastocyst is not different from brain dead individual in terms of personhood. Moreover, the advocates of hES cell research, according to him, argue that the fertilization period cannot be accepted as the landmark for personhood because fertilization itself is a process that last for about 30 hours.

Furthermore, the advocates of hES cell research argue that the blastocyst is not a person which is usually measured by individuality, since the primitive streak has not appeared to forestall twinning (Austriaco, 2008). Also, some scholars argue that the human person is first of all a mammal, hence since the blastocyst lacks the traits of mammals; it cannot be treated as human person (Ibid). Reacting to the argument that the blastocyst is a person with its own genetic individuality as signifies by the genome, Boomsma (2004) argued that genetic composition or genome alone cannot define personhood due to the phenomenon of twinning. In response to Austriaco's argument from body axes, it is worthy of note that even lesser animals have body axes, hence it cannot serve as the criterion for human personhood. Yet, it is doubtful if the presence of body axes is an object of empirical science. Finally, it is worthy of note that there is no official scientific position on the personhood of the blastocyst, due to the fact that personhood is not an object of scientific inquiry. However, it could be deduced that the scientists ascribe personhood to the embryo in a gradualist sense - using the ladder of stages of embryonic development.

Legal Perspective: Although legal position cannot absorb itself of the influence of religion and science, legal position on the personhood of the blastocyst is fairly distinct. Olusoga Olopade (2008) argues that the law does 
not cloth the blastocyst with the status of human personhood. According to him, the embryo is regarded in law to be an ventre sa mere - yet for some legal purposes, it could be regarded as already having existence of its own. However, Olopade maintains that "the current position of the law does not clothe a foetus with legal personality until it is born" (Ibid). To be born, in legal sense, means "the child must be completely extruded from the mother's womb;" and it must have existence independent of the mother's body (Ibid). This is the condition considered in the section 220 of the Penal Code of the Federal Republic of Nigeria. This condition is corroborated in section 307 of the Criminal Code of Federal Republic of Nigeria. In spite of that, Olopade (2008) argues that there is no strict certainty in relation to the precise moment at which the foetus comes under the protection of the law. However, in some other jurisdiction the embryo is granted legal protection at vitality (about 24 weeks from conception) - example is Roe vs Wade (Brody, 1994). On the other hand, the legal systems of Nigeria and Britain do not definitely clothe the embryo with personhood until birth. Hence, in Britain, for example, hES cell research with blastocyst is permitted (Brownsword, 2005). So, in law, the blastocyst is not a person as such.

Philosophical Perspective: Jim Unah rightly argued that man is the subject of philosophical inquiry. A lot have been said about the personhood status of the blastocyst. What does philosophy have to say on this debate? Nina Rosenstand (2006) asks in her book The moral of the story:

What does it mean to be human? Are the criteria physical? Does a being have to look human in order to be human? And I dare ask: what does it mean to look human? This question is very significant to the future of hES cell research. Several answers have been advanced from various perspectives, some of which we have considered above. But what does it mean to look human? Rosenstand says "a traditional answer is ... a creature that walks upright on two legs but is not a bird" (Ibid). However, she argues that these are hardly sufficient criteria. Noonan (1994) argues, on the contrary, that any creature that has human genetic code is human. Now, how do you determine that a genetic code is human? Yet Boomsma (2004) argue that genetic composition alone cannot define human personhood. Upon this argument, Mary Warren (1994) established criteria for personhood, namely: consciousness, reasoning, self-motivated activity, communicability, self-awareness. Edmund Husserl avers that consciousness is an "outward moving vector" that is directed at something - the external world. Based on this consciousness criterion alone, the blastocyst can never become a human person. However, Rosenstand argues that even the new born baby would be excluded by Warren's criteria for personhood.Unfortunately, very many philosophers have talked about what it means to be a human person but only a scarcely few talk about the beginning of human life. Hug (2006) noted that "a traditional view, held by St. Thomas Aquinas, was that the soul entered the male fetus at the $40^{\text {th }}$ day and the female foetus at the $90^{\text {th }}$ day" thereby making the embryo becomes human. From St. Augustine, Hug wrote: "the unformed early foetus was thought to lack a human soul because it lacked sentience" (Ibid). In other words, the blastocyst, for St. Aquinas and St. Augustine, is not a human person at all.

Buddha argues that a human person, that has life, must be capable of being harm (Promta, 2004). But what does it mean to have life? English Jurists say that a human being that has life must be able to cry (Olopade, 2008). Plato (1997) says human person is a combination of body and soul. Rene Descartes (1994) argues that a human person is a being that thinks. Jean-Paul Sartre (1994) argues that "man is freedom" - by freedom he mean human being is a choice-making being. So Sartre criterion for person is the ability to make choice. Jim Unah (2005) argues, however, that human being is "a bundle of possibilities" and not a "fixed entity" - hence human personhood cannot be identified with definite physical attributes. In addition, Rosenstand (2006) argues that human "being do not just consist of DNA but are also the sum of their experiences." Using a clone as an example, she argues that even the clone cannot be the exact individual as its DNA donor.

To get the 'same' individual as its DNA donor, we would have to create a completely identical environment for the individual to grow up in - nature plus nurture. And even if that were accomplished, we have to factor in what we might call situation awareness, what some would call free will (Ibid).

This explains the reason twins with the same blastocyst can never be the same personality. This means that no two persons are the same by any standard. We do not have man as such but individual human beings. Teo and Calbreath (2006) however argued that the blastocyst is a full member of the species Homo sapiens by the virtue of its heritage and genetic constitution. It is important to note that what Teo and Calbreath do not understand is the genealogical meaning of the concept Homo Sapien - that it is not genetic code that makes Homo a Sapien.Furthermore, Unah (2005) argues that to be a human person is to be a being that exist, and to exist is a possibility. Yet human being can only exist in the world environment. Outside the physical world the human person is impossible. The fact that human person is not a particular state of affairs but a possibility, a happening, an event, which dynamically continue to occur, means that human being is not a mere physiological structure. To be a human being at all you have to first exist, happen, occur in the phenomenological world. Based on this argument the blastocyst can never be considered as a human being. Besides, a few philosophers had argued that the ensoulment marks the beginning of human personhood. This notion is based on a more 
fundamental notion that human being is a combination of body and soul. Although the said philosophers had failed to agree on when ensoulment takes place, it is important to subject the concept to a crucial test. For example the soul and mind had been interchangeably used by philosophers, yet we ask: is there such a thing called soul. If the said soul is located in time and space, where did it come from, when, how, why; and when shall it depart, why, how, to where? If it is argued that the embryo is loaded with such a mundane thing called soul, does it mean that the pregnant mother was possessed of two souls and why didn't they clash?

\section{CONCLUSION}

Finally, what we have drawn from the exercise so far is that human person is not merely a bundle of cells but that the human person can only be realized in experience, in the physical world, in the community. Human being is not merely a genetic code, so many thing combine to form the human reality, yet the human being, the human person can only be realized in the phenomenal world. Therefore since the blastocyst is not a member of this community, by first appearing or happening in the world of phenomena, then it does not exist other than the way other somatic tissues exist, and cannot be considered as human person. So the hES cell research is not an encroachment on humanity at all. The stem cell research should be fully encouraged.

\section{REFERENCES}

[1] Austriaco, N. (2008): Understand Stem Cell Research: Controversy and Promise. New Haven: Knights of Columbia Supreme Council.

[2] Avasthi, S., Srivastava, M. S., Singh, A. \& Srivastava, M. (2008): "Stem Cell: Past, Present \& Future - A Review Article" in Internet Journal of Medical Update 2008, Vol. 3, No.1

[3] Boomsma, R. A. (March, 2004): "Embryonic Stem Cells and a Reformed Christian Worldview" in The Perspectives on Science and Christian Faith.

[4] Brody, B. (1994): "The Morality of Abortion" in Tom L. Beauchamp \& LeRoy Walters (Eds.) Contemporary Issues in Bioethics, $4^{\text {th }}$ ed. California: Wadsworth Publication Co.

[5] Brownsword, R. (2005): "Regulating Stem Cell Research in the United Kingdom: Filing in the Cultural Background" in Wolfgang Bender, Christine Hauskeller \& Alexandra Manzei (Eds.), Crossing Borders. Munster: Agenda Verlag.

[6] Criminal Code and EFCC Act, Laws of the Federation, 2004

[7] Hug, K. (2005): Sources of Human Embryo for Stem Cell Research. Ethical Problems and their Possible Solutions, Kaunas University of Medicine Lithuania.

[8] Hug, K. (2006): Therapeutic Perspective of Human Embryonic Stem Cell Research Versus the Moral Status of a Human Embryo - Does one have to be compromised for the other? Kaunas University of Medicine, Lithuania.

[9] Ikube, J. (July, 2010): Creativity, A Public Lecture Presented at the University of Lagos, Nigeria.

[10] Iroegbu, A. (2005): "Glossary of Bio-Medical Terms" in Pantaleon Iroegbu and Anthony Echekwube (Eds.), Ethics: General, Special and Professional. Ibadan: Heineman Educational Books.

[11] Iroegbu, P. (2005): "Beginning, Purpose and End of Life" in Pantaleon Iroegbu and Anthony Echekwube (Eds.), Ethics: General, Special and Professional. Ibadan: Heineman Educational Books.

[12] Iroegbu, P. (2005): "Stem Cells: Technology and Ethics" in Pantaleon Iroegbu and Anthony Echekwube (Eds.), Ethics: General, Special and Professional. Ibadan: Heineman Educational Books.

[13] Knowles, L. E. (Retrieved in 2010): Religion and Stem Cell Research, Stem Cell Network. www.scn.com

[14] Lasker, D. J. (2005): "Stem Cell Research and Therapy: Jewish Views" in Wolfgang Bender, Christine Hauskeller \& Alexandra Manzei (Eds.), Crossing Borders. Munster: Agenda Verlag.

[15] Noonan, J. T. (1994): “An Almost Absolute Value in History” in Tom L. Beauchamp \& LeRoy Walters (Eds.), Contemporary Issues in Bioethics $4^{\text {th }}$ ed. California: Wadsworth Publishing Co.

[16] Oliphant, J. (2007): OCR Religious Ethics for AS and A2. London: Routledge.

[17] Olopade, O. (2008): Law and Medical Practice in Nigeria. Ibadan: College Press \& Publishers Ltd.

[18] Penal Code CAP. 89, Laws of the Federation

[19] Plato (1997): Republic, John Llewelyn Davis and David James Vaughan (Trans.) Hertfodshire: Wordsworth Editions Ltd.

[20] Promta, S. (January, 2004): Human Cloning and Embryonic Stem Cell Research: A View from Therauda Buddhist Morality, Philsoophy Department and Center for Buddhist Studies, Chulalongkorn University, Bangkok.

[21] Rosenstand, N. (2006): The Moral of the Story: An Introduction to Ethics $5^{\text {th }}$ ed. New York: McGraw Hill Co. Inc.

[22] Sartre, J. P. (1994): "Existentialism is a Humanism" in Donald C. Abel, Ed. Fifty Reading in Philosophy. New York: McGraw-Hill Inc. 
[23] Segura, J. V. and Delgado, M. (Retrieved in 2010): Values in Controversies: Stem Cell Research, Departmento de Filosofia, Universidad Autonoma de Barcelona, Spain.

[24] Teo, A. and Calbreath, D. (September, 2006): "Embryonic Stem Cells and a Reformed Christian Worldview: A Response to Robert Boomsma," in The Perspectives on Science and Christian Faith.

[25] Unah, J. I. (2005): On Being: Discourse on the Ontology of Man. Lagos: Fadec Publishers.

[26] Warren, M. A. (1994): "On the Moral and Legal Status of Abortion" in Tom L. Beauchamp \& LeRoy Walters (Eds.), Contemporary Issues in Bioethics $4^{\text {th }}$ ed. California: Wadsworth Publishing Co. 